\title{
VEIGA, Teresa. As enganadas. Rio de Janeiro: 7Letras, 2006, $117 \mathrm{p}$.
}

\author{
Denis Leandro Francisco \\ Universidade Federal de Minas Gerais
}

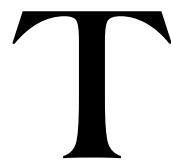

eresa Veiga é o pseudônimo de uma das vozes mais enigmáticas da recente literatura portuguesa, em particular do conto, gênero que lhe valeu, em 1992, o Prêmio de Ficção do Pen Clube e o Grande Prêmio Camilo Castelo Branco da Associação Portuguesa de Escritores. No site do IPLB (Instituto Português do Livro e das Bibliotecas), a biografia da autora informa apenas que ela nasceu em 1945, formou-se em Direito em 1968, em Letras em 1980 e trabalhou no Registro Civil entre 1975 e 1983.

A atmosfera obscura que envolve essa personalidade literária ainda pouco conhecida entre nós e de quem nem mesmo o nome conhecemos ao certo - ressoa em todos os seus escritos, como nos contos reunidos sob o título de $A s$ enganadas, livro lançado em 2003 e publicado no Brasil em 2006 pela editora 7letras. Nas três narrativas que compóem o volume, a autora joga de forma bastante sutil e engenhosa com encobertos e significados latentes, muitas vezes capturando de imediato a atenção do leitor.

O primeiro conto - "A morte de um jardineiro” -, sem dúvida o mais bem trabalhado deles, desenvolve-se a partir da morte do jardineiro da família do Dr. Paulo Guerra, governador civil, casado com Rosalia, uma mulher que "nascera do outro lado da fronteira” (p. 8) e que fora para Portugal ainda criança, fugida da guerra na qual perdera toda sua família. Rosalia completou os estudos no colégio das dominicanas e, ao voltar para casa, resignou-se a se tornar enfermeira em tempo integral de uma parenta idosa e doente: foi então que conheceu o governador em uma festa de batizado e se casou com ele. 
A morte repentina do jardineiro da família no dia da festa anualmente oferecida pelo governador desencadeia uma série de situações que põem em suspeita a fidelidade de Rosalia, que fica absolutamente transtornada pela morte daquele que todos pensavam ser somente um mero subalterno. As suspeitas de um envolvimento amoroso entre a esposa do governador e o empregado não são nunca confirmadas - tampouco desmentidas - e a narrativa desenrolase e se encerra sobre esse fio de incertezas e de enigmas, de possíveis enganos.

O fato é que a leitura de um livro, significativamente escolhido ao acaso na biblioteca e cujo título não nos é revelado, fora o que alertara Rosalia para sua existência medíocre, durante quase dez anos, ao lado do governador. Simbolicamente representando a força do acaso na existência humana - viés que Teresa Veiga tanto incorpora aos seus textos -, bem como a força de uma leitura não dirigida, mas com a participação ativa do leitor, esse livro funciona, na narrativa, como um divisor de águas. A leitura despretensiosa desse livro "escrito por um escritor famoso e não uma obrinha acerca do coração feminino" (p. 29) insinua uma concepção de literatura como lugar no qual o sujeito se conhece e não como um espaço onde ele se reconhece, como se fosse um espelho reproduzindo, mimeticamente, o eu e o mundo.

O conto encena ainda uma crítica à sentimentalidade da literatura romântica: pode-se ler, nas considerações do governador, uma crítica irônica ao derramamento sentimental da mulher e, indiretamente, ao derramamento da estética romântica: “(..) a apologia que ela fazia do jardineiro tinha qualquer coisa de destemperado e romântico que parecia obra de um cérebro confuso e de muita fantasia." (p. 33). A personagem Rosalia encarna, assim, o amor, a paixão, a ausência da lei, em oposição à figura da lei que o marido representa. Outras "infrações" intertextuais da lei podem ser recuperadas a partir do triângulo amoroso que Teresa Veiga insinua: na literatura universal, Madame Bovary; na portuguesa, O Primo Basílio e, na nossa literatura brasileira, Dom Casmurro: todas as três protagonistas femininas desses romances - Emma Bovary, Luísa e Capitu - também lêem e são "pervertidas" pela leitura, todas elas agregam, de certa forma, o incompreensível e o heterogêneo, a dúvida desestabilizadora que impulsiona a narrativa. Mas, enquanto Flaubert, Eça e Machado de Assis aceitam punir com a morte suas protagonistas infiéis (?), Teresa Veiga, fazendo valer seu lugar de enunciação e sua voz feminina, decide-se pela não- 
punição: Rosalia sobrevive ao marido - que, este sim, tem reservado para si um desfecho sarcástico e caricato.

O segundo e terceiro contos perdem algo da força simbólica encontrada no primeiro. Em "Danças Húngaras de Brahms”, Faustina, mãe de Fábio, suspeita que o filho seja homossexual. Contrata, então, um detetive de nome Lamartine que descobre que o rapaz é dançarino, mas não comprova nenhum envolvimento homossexual. Tem-se, também nesse segundo conto, a inserção e a permanência da dúvida como propulsora da narrativa ficcional: enquanto no conto anterior tinha-se a figuração do amor conjugal e a dúvida quase que inerente a esse tipo de relação, tem-se agora a figuração do amor materno e a incerteza que também o atravessa, desestabiliza e constitui. Infelizmente, toda a situação tensa que a narrativa cria é simploriamente resolvida por meio do artifício do "devaneio onírico", que simplifica muito o conflito que o conto propõe, mas felizmente não dissolve a dúvida estrutural: essa mãe que se julga enganada pelo filho pode, perfeitamente, ter, ela mesma, se enganado em suas suspeitas, pode ter sido vítima de um "auto-engano".

Em "Confidência Barreirense", Teresa Veiga, personagem-narradora, escreve uma carta a amiga e editora
Luísa Costa Gomes, que lhe havia solicitado um conto para ser publicado na revista Ficções - onde o texto foi, de fato, originalmente publicado ( h t t p:// www.ficcoes.org/ b i b l i o t e c a _ conto/ confidencia_barreirense.html), relatando acontecimentos que teriam ocorrido com ela há mais de meio século, quando assumiu o cargo de Conservadora do Registro Civil do Barreiro, em Portugal. Teresa Veiga narra, então, como conheceu a família Martinó, que sofre de uma doença degenerativa, envelhecendo precocemente, e como foi "enganada" ao realizar às pressas o casamento civil do filho, Luís Martinó, e Adelina, filha da empregada, morta e grávida de Luís. A escrita sem happy end de Teresa Veiga mostra essa tabeliã que é ela mesma constrangida por ter sido ludibriada, levada a realizar esse casamento ilegal e inquieta por tentar entender como se deixou enganar tão ingenuamente. Os três breves contos de As enganadas servem ainda como espécie de alerta: é preciso que o leitor aprenda a lição das duas Teresas - a da personagem barreirense e a daquela que escreve e se faça menos ingênuo, a fim de não se deixar enganar, também ele, pela prosa hábil e deliciosamente maliciosa da autora. 